\title{
Antimicrobial activity of two medicinally important plants (Juniperus excelsa and Ephedra intermedia) of Gharshinan Rodh Malazai area, District Pishin, Balochistan-Pakistan
}

Mujeeb-Ur-Rehman ${ }^{1 *}$, Saeed-Ur-Rehman ${ }^{1}$, Saadullah Khan Leghari ${ }^{1}$, Abdul Kabir Khan Achakzai ${ }^{1}$, Muhammad Idrees $^{2}$, Khalil-UrRehman $^{3}$, Arifa Malik ${ }^{4}$, Basra Sher Zaman ${ }^{1}$ and Bakht Zareen ${ }^{1}$

1. Department of Botany, University of Balochistan Quetta, Pakistan

2. Govt. Boys High School Gharshinan, Pakistan

3. Govt. Post Graduate Science College Quetta, Pakistan

4. Govt. Girls Post Graduate College Kawari Road Quetta, Pakistan

*Corresponding author's email: mujeeburrehman302@gmail.com

Citation

Mujeeb-Ur-Rehman, Saeed-Ur-Rehman, Saadullah Khan Leghari, Abdul Kabir Khan Achakzai, Muhammad Idrees, Khalil-Ur-Rehman, Arifa Malik, Basra Sher Zaman and Bakht Zareen. Antimicrobial activity of two medicinally important plants (Juniperus excelsa and Ephedra intermedia) of Gharshinan Rodh Malazai area, District Pishin, Balochistan-Pakistan. Pure and Applied Biology. Vol. 11, Issue 2, pp577-585.

http://dx.doi.org/10.19045/bspab.2022.110058

Received: 00/05/2021 Revised: 00/07/2021

Accepted: $28 / 08 / 2021$

Online First: 02/09/2021

\section{Abstract}

The principal objective of this research was to explore the medicinal capability of two therapeutically significant plants species i.e., Juniperus excelsa and Ephedra intermedia. The contents of root and shoot of Ephedra intermedia, and the substance of leaves, berries and mixture of Juniperus excelsa extricate by methanol solution. These different parts of plant were inspected against some pathogenic organisms (bacterial strains) through agar well diffusion procedures. Juniperus excelsa is a significant blossoming restorative plant having a place with the Cupressaceous family. Juniperus excelsa had a wide scope of antimicrobial activities against different kinds of microbial strains (Staphylococcus aureus, Thiobacillus ferrooxidans, Thiobacillus Thiooxidans, Leptospirillum ferrooxidans and Escherichia coli). All the Gram positive and Gram-negative microscopic organisms were vulnerable to fundamental oil of leaf and fruit of Juniperus excelsa. Ephedra intermedia are one of the main plants in customarily and medicinally significant as the organic beginning of unrefined medications. The concentrate about antibacterial action of Ephedra intermedia were considered in against four bacterial strains (Staphylococcus aureus, Escherichia coli, Pseudomonas fluorescens and Bacillus subtilis). What's more, the after effects of this investigation affirmed that the metabolic concentrate of Ephedra intermedia displayed a significant antibacterial action. In conclusion, the concentrate of Ephedra intermedia could be a significant wellspring of phenolic segments with antibacterial activity. Resultantly, either the leaf, berries and mixture (leaf+berries) of Juniperus excelsa or the root and shoot of Ephedra intermedia have profoundly compelling against the microorganisms, especially bacteria. The research area has the abundant number of Juniperus excelsa and Ephedra intermedia which are never discussed by researchers. The different parts of these aforementioned plants have highly contents of chemicals which resist the microorganisms especially variant types of bacteria.

Keywords: Antibacterial activities; Baluchistan; Berries; Leaves; Medicinal plant; Seed; Stem 


\section{Introduction}

Utilization of medicinal plant species as medication is one of the routinely used practices in subcontinent. Plants have consistently been a cure for various infections because of quality of numerous phytochemical compounds. Medications that are acquired from home grown sources have a wonderful impact in forestalling and restoring deadly sicknesses. Individuals in most created nations utilize conventional medication in medical services [1]. Locally, different plants are utilized as drugs at the preliminary levels in various areas of the world. Mostly of individuals are subject to natural plants for medical care [2].

Authenticated by WHO, that Gentamycin like biological drug further not useful for prevention of any microbes. There are multiple names of drugs which are effective once but do not show its activity against bacterial strains [3].

Some medication by plants has emblems that causes a various abnormal feature as like as side effects in human beings. These abnormal characteristics of plants compelled the ethno botanist for seeking drugs which are affordable, biologically degradable and with least side effects [4].

Traditionally ethno medicinal plants have a vital role in the treatment of developed nations. Plants which belong to herbs have been utilized for the treatment of human diseases due to these is medicinally important [5]. Cassia alata (L.) is an sin qua non medicinal plant indigenous to Asian states, particularly South Asian States. The research parts of the included plant were experimented to show ethno botanical properties such as antimicrobial and painkiller. The treatment of ring worm took place with the help of leaves of aforementioned plant. It is traditionally high beneficial against dermal diseases in human beings and cattle [6].

Over population may cause the needy components of life such as food, cloth and hygiene. The homeopathic uses of plants have a great concern over highly effective and least side effects in biota as compared to allopathic medicine [7] concluded that the use of ethno botanical plants by observing their medical application through update research. Long range of medicinally important plant parts are utilized as raw components for medicines. However, numerous plants have been observed for antibacterial activity but still some local plants of some areas remain under exploration which is unexplored for the diverse antimicrobial potential that the local community is carelessly utilizing [8]. The growing scene of microbes resistance to the affordable antibiotics has felt the need to examine for coming and new antimicrobial agents.

Gharshinan Rodh Malazai Pishin is the study area which is located located in the northwest of Baluchistan, in the east of the province near the border with Afghanistan. In summer season temperature can reach $40{ }^{\circ} \mathrm{C}\left(104^{\circ} \mathrm{F}\right)$. In the winter, temperatures can down to freezing point. The Latitude is $30^{\circ} 34^{\prime} 54^{\prime \prime} \mathrm{N}$ and Longitude is $66^{\circ} 59^{\prime} 38^{\prime \prime} \mathrm{E}$. Pishin elevation above sea level is $1536 \mathrm{~m}=$ $5039 \mathrm{ft}$. This area has extremely low rainfall and evaporation is very high on the one hand and on the other hand with the increasing demand for urban, agricultural and industrial, faces a severe water stress [9].

Psammogeton comprises of 6 species, majority is found in sandy hills of deserts in various parts of Turkmenistan, Pakistan, Afghanistan and Iran (Nasrabadi et al., 2009). P. biternatum Edgew normally known as "izbotk" in Kalat and "sparki" in different locales. It is a yearly species that goes from 15 to $22 \mathrm{~cm}$ long. It has little blossoms that are white or pink in shading. It blossoms from March to April. It is a yearly plant that is situated in a few locales of District Kalat. Psammogeton biternetum is privately utilized for the fix of intestinal sickness, challenging hack, typhoid and chest infections by individuals of district Kalat [10].

$P$. biternatum Edgew seeds are extremely useful for post pregnancy contaminations (after conveyance) if ground and blended in water and taken between suppers [11]. 
Researchers reported about those plants which increases the antimicrobial activity against the resistant strains of bacteria. Researchers also studied the antimicrobial agents evolution of Solanum incanum, and Hydnora johanis against Enterococcuss feacalis by utilizing disc diffusion method [12].

Ephedra sinica is the principle plant beginning of the Chinese home grown medication Mahuang, Ephedra Herb. 85 examples of $E$. sinica, gathered across eastern China, Mongolia, and Buryatia (Russia), were concentrated anatomically and artificially to clarify the neighborhood varieties and the connection between ecological elements and the varieties. The outcomes showed that examples filled in more dry conditions would in general have a more twisted epidermis, more circular tubers, and more sub epidermal fiber packages anatomically, and contained more all-out ephedrine alkaloids. These examples likewise had a high pseudoephedrine content. These achievements suggest that Ephedra herb with great quality ought to be gathered from parched fields, and the substance quality can be assessed by noticing the anatomical attributes [13].

A quantitative survey was conducted in 32 stands of juniper (Juniperus excelsa) in four adjacent districts of Baluchistan [Baluchistan] Pakistan. No other tree species was recorded in the study area. Data are tabulated on the herb, shrub and grass composition of the stands - only 11 species were found apart from juniper. Mean density of juniper was 105/ha and basal area 18.4 $\mathrm{m}^{2} /$ ha. Density and basal area were significantly correlated. Density of female trees was higher than that of male trees. Healthy trees produced only $21 \%$ of heavy seeds. Trees were slow growing (18 years/cm radial growth rate), and many were unhealthy and over-mature; there was no seedling regeneration. Details are given of 5 morphological tree forms found in the area. Leaf and soil analysis were also performed. Sandy clay loam with a calcareous nature was the dominant soil. No correlation was observed between tree density, basal area and soil characteristics. It is concluded that these forests are rapidly degrading due to human disturbance [14].

In pakistan $80 \%$ individuals are living in provincial regions. They are reliant upon therapeutic plants. Artemisia indica is utilized for asthma, uncontrollable and anxious impact however Medicago falcata contains enormous quantities of nutrients and proteins [15].

Wild Garlic (Allium ursinum) tissues (leaf, stem and root) were meant something negative for microorganisms which are microbes and growths [16].

Plants are the best hotspot for restorative medicines and drug purposes because of plants contain exceptionally measure of optional metabolites fit as a fiddle of phenolic compounds [17].

Balochistan is the rich hotspot for therapeutic plants however (Ahmed et al., 2012) dealt with four significant plants.

Thus, Berbarus balochistanica has exceptionally powerful one and been most reduced least inhibitory fixation. Besides, the impact of Canabus sativa was accounted for that it has profoundly antimicrobial specialists and Minimum Inhibitory Concentration (MIC) of positive microbes when contrasted with negative microorganisms. Just as, additionally decided the poisonousness of cell from certain plants of Baluchistan [18].

\section{Material and Methods}

\section{Sampling collection, identification and drying of plant materials}

For examining the antimicrobial agents of plants, primarily the sample of collection is mandatory for knowing and identification of the plant parts specimen. The whole parts of the plants were dried in shady area for protection of their agents against pathogens (Bacteria). The plants were identified by the taxonomist, University of Baluchistan Quetta.

\section{Preparation of plant extracts}

The plant parts samples (Leaf and Stem) were washed thoroughly 2 to 3 times with tap water and once with sterile water for 
protection of contaminated constituents of environment. Furthermore, shady and air dried powder utilized for the purpose of extraction of plants. The plant parts cut down into small parts and dried in shady area at $32-35 c^{\circ}$. Through electric blender $25 \mathrm{~g}$ of each plant specimen changed into powder form. Methanol used for extraction of plant samples. After 24 hours, whatman filter paper used for fine filtration of extract. Then the filtered liquid concentrated in circulatory (rotatory) flask evaporator, until dried [19].

\section{Test organisms}

For this study Bacterial strains are used. The test organisms will be obtained from, Department of Microbiology and Microbiology lab from University of Baluchistan. All the bacterial strains grew in nutrient broth and incubated at for $37 \mathrm{c}^{\circ}$ at least two days [19].

\section{Agar well diffusion method}

Agar well diffusion method is a general technique for determination of antimicrobial activity of the plants extracts. Through this phenomenon agar plate surface inoculated by increasing a volume of the microbial inoculant over the total agar surface area. Further, a tiny perforate with a diameter of 6 to $8 \mathrm{~mm}$ punched objectively (without germs) with a sterile cork borer and a volume $(20-100 \mu \mathrm{L})$ of the extract solution at desired concentration inserted into the well. In addition, agar plates kept in under favorable conditions which are depending upon the test microbes. The agents against microbes spread out in the agar medium and prevent the growth of the bacteria [20].

\section{Result}

Leaves and fruits of $J$. excelsa were commonly moderate in amounts of organic contents like alkaloids tannins, flavonoids and saponins. The result of the antibacterial activity of the J.excelsa contents by the disc diffusion method is given in the (Table $1 \&$ Fig. 1). The microorganisms tested were Escherichia coli, Thiobacillus ferrooxidans $(T B F)$, Leptospirillum ferrooxidans (LSF) Thiobacillus Thiooxidans and Staphylococcus aureus. All bacterial species tested were found sensitive to the essential oils contents of $J$. excelsa berries, leaves, and mixture with the inhibition zones ranging from, $12.6 \mathrm{~mm}$ to $23.3 \mathrm{~mm}, 11.8 \mathrm{~mm}$ to $22.6 \mathrm{~mm}$ and $12.7 \mathrm{~mm}$ to $23.1 \mathrm{~mm}$ respectively. The higher value was found for tested Gram- negative bacteria as compared to tested Gram positive bacteria. As per above discussion, it is concluded that the highest inhibition zone reported for Escherchia coli which are $22.6 \mathrm{~mm}, 23.1 \mathrm{~mm}$ and $23.3 \mathrm{~mm}$ for leaves, mixture (leaves + Berries) and berries respectively. As well as the lowest inhibition zone accounted for Staphylococcus aureus which are $11.8 \mathrm{~mm}$, $12.6 \mathrm{~mm}$ and $12.7 \mathrm{~mm}$ for leaves, berries and mixture. The average inhibitory zones of leaves, berries and mixture are $17.5 \mathrm{~mm}$, $18.2 \mathrm{~mm}$ and $18.56 \mathrm{~mm}$ respectively against tested five species of bacteria. The three parts of Juniperus excelsa has slightly difference against the microbes, especially bacteria. On the basis of average, the leaves have the lowest $(17.5 \mathrm{~mm})$ inhibitory contents against bacteria, but the berries have the highest $(18.56 \mathrm{~mm})$.

Table 1. Antibacterial activity of Juniperus excelsa determined by Agar Well Diffusion Method

\begin{tabular}{|c|c|c|c|c|}
\hline Bacterial Species & Berries & Leaves & $\begin{array}{c}\text { Mixture } \\
\text { (Berries+ Leaves) }\end{array}$ & Average \\
\hline Staphylococcus aureus & 12.6 & 11.8 & 12.6 & 12.3 \\
\hline Thiobacillus ferrooxidans (TBF) & 23.2 & 19.7 & 23.2 & 22.0 \\
\hline Thiobacillus Thiooxidans & 17.1 & 16.7 & 17.2 & 17.0 \\
\hline Leptospirillum ferrooxidans (LSF) & 14.8 & 16.9 & 15.8 & 15.8 \\
\hline Escherichia coli & 23.3 & 22.6 & 23.1 & 23.0 \\
\hline
\end{tabular}

Inhibition Zone in $\mathrm{mm}$ (millimeter) 
This study exhibited that all extracts had good to satisfactory results against bacterial strains. Methanol extracts showed extreme potential as compared to other extracts against all Bacterial species (Table $2 \&$ Fig. 2 ). This might be for the reason that of many phytochemical compounds like terpenoids, flavonoids, polyphenol compounds as well as tannins expected to be extracted in methanol. The shoot and root extracts of Ephedra intermedia were tested against four bacterial strains (Staphylococcus aureus, Bacillus subtilis, Pseudomonas fluorescens and Escherchia coli). The roots of $E$. intermedia have the highest inhibitory zone for $S$. aureus and the lowest for B.subtilis which are $22 \mathrm{~mm}$ and $15 \mathrm{~mm}$ respectively. As well as, the shoots have the lowest inhibitory zone for B. subtilis $(11 \mathrm{~mm})$ and the highest for $S$. aureus $(19 \mathrm{~mm})$. The average of roots contents has the higher antibacterial activity as compared to shoots which are 18.25 and 15. The roots and shoots of E. intermedia have the maximum antimicrobial (Antibacterial) activity against the $S$. aureus of bacteria. However, the roots and shoots of $E$. intermedia have recorded the minimum activity as per tested to $B$. subtilis. The average of roots and shoots contents against the tested bacteria: Staphylococcus aureus has the highest inhibition zone but the Bacillus subtilis has the lowest one as compared to other species of bacteria.

Table 2. Antibacterial activity of Ephedra intermedia determined by Agar Well Diffusion Method

\begin{tabular}{|c|c|c|c|}
\hline Bacterial Species & Shoot & Root & Average \\
\hline Staphylococcus aureus & 19 & 22 & 20.5 \\
\hline Bacillus subtilis & 11 & 15 & 13 \\
\hline Pseudomonas fluorescens & 13 & 17 & 15 \\
\hline Escherichia coli & 17 & 19 & 18 \\
\hline
\end{tabular}

Inhibition zone in mm(millimeter)

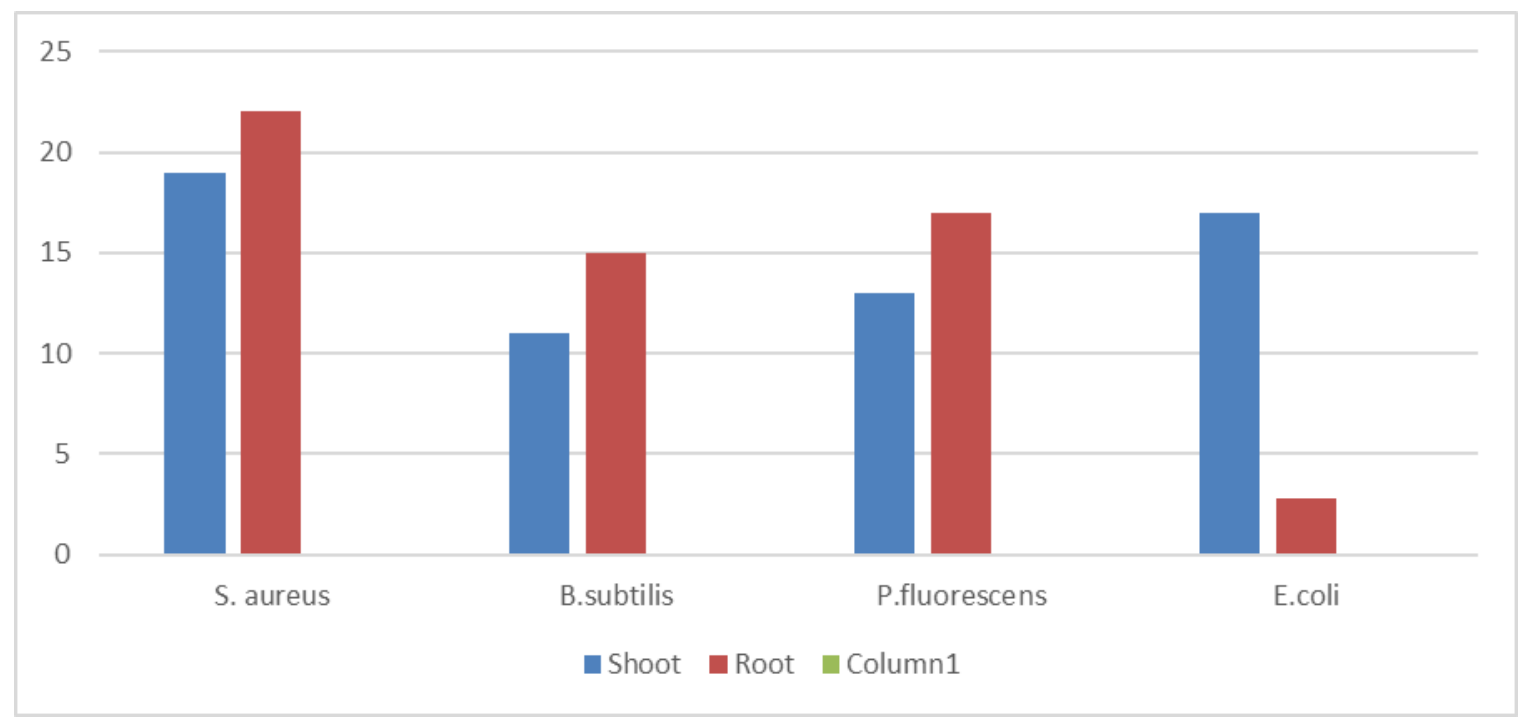

Figure 1. Antibacterial activity of Ephedra intermedia determined by Agar Well Diffusion Method 


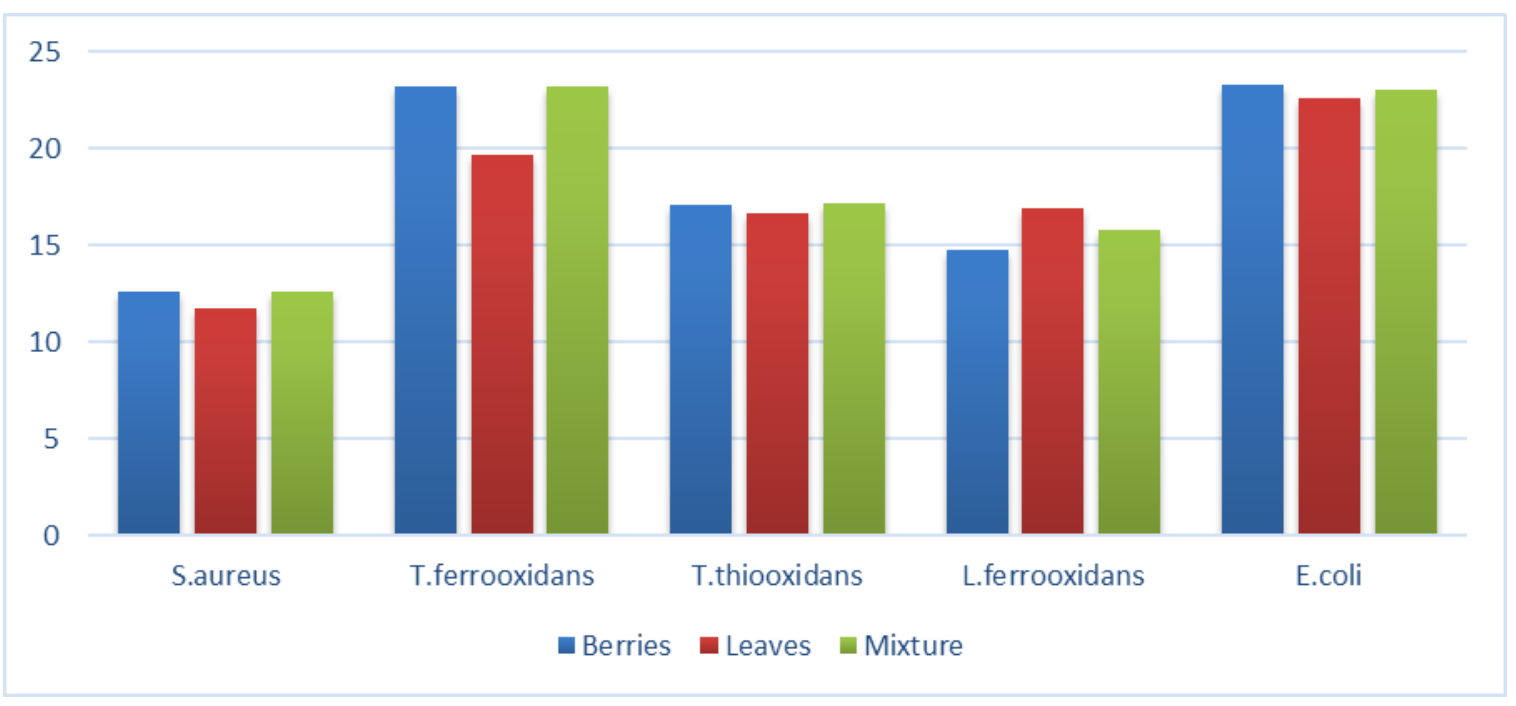

Figure 2. Antibacterial activity of Juniperus excelsa determined by Agar Well Diffusion Method

\section{Discussion}

Plants contain contents in the form of different chemical compounds which may be highly and sometimes slightly resistant to micro-organisms especially bacteria. Various parts of the plants have different constituents which are responsible for inhibiting the activities of microbes. The selected area of Gharshinan Rodh Malazai which is extraordinarily rich, of the two medicinally important plants: Juniperus excelsa and Ephedra intermedia. J. excelsa is mostly occur in mountainous area but the $E$. intermedia is occurring in peak of the mountains, as well as in valleys.

According to research studies both species either J. excelsa or E.intermadia are the rich source of antimicrobial activities specially antibacterial. For this investigation purposes, the leaves, berries and mixture (leaves and berries) of Juniperus excelsa are subjected against five strains of bacteria; Staphylococcus aureus, Thiobacillus ferrooxidans, Thiobacillus Thiooxidans, Leptospirillum ferrooxidans and Escherichia coli. As well as Ephedra intermedia parts (Roots and shoots) are also subjected against four strains of bacteria: Staphylococcus aureus, Escherichia coli, Pseudomonas fluorescens and Bacillus subtilis. All the parts of these two selected plants have the ability of resist against bacteria.

The microorganisms tested were Staphylococcus aureus, Thiobacillus ferrooxidans (TBF), Leptospirillum ferrooxidans (LSF) Thiobacillus Thiooxidans and Escherichia coli. All bacterial species tested are sensitive to the essential oils of J. excelsa leaves, berries and mixture with the inhibition zones ranging from $11.9 \mathrm{~mm}$ to $22.7 \mathrm{~mm}, 12.7 \mathrm{~mm}$ to 23.4 $\mathrm{mm}$ and $12.8 \mathrm{~mm}$ to $24.1 \mathrm{~mm}$ respectively. The lower values were found for the tested Gram-positive bacteria as compared to the tested Gram-negative bacteria. Omani authors reported that the essential oil of $J$. excelasa berries does not contain any antimicrobial activity against Staphylococcus aureus and Escherichia coli which is contradictory to the present study [21]. In another study the authors reported that J. excelsa essential showed less antimicrobial activity against the tested microorganisms [22]. It has been reported that the essential oils are usually believed to be active when they show minimum inhibitory concentration (MICs) of 128 $\mathrm{mg} / \mathrm{ml}$ and/or below [23]. The essential oils isolated from leaves and twigs of J. excelsa growing wild in Lebanon showed antimicrobial activity against Staphylococcus aureus but Escherichia coli 
was resistant [24]. Therefore, the presented results of antimicrobial activity of J. excelsa essential oils similarities and dissimilarities are found in literature that could probably be due to the diverse percentage of chemical constituents present in essential oils.

All bacterial species tried are touchy to the fundamental oils substance of $J$. excelsa berries, leaves, and blend with the hindrance zones going from, $12.6 \mathrm{~mm}$ to $23.3 \mathrm{~mm}, 11.8$ $\mathrm{mm}$ to $22.6 \mathrm{~mm}$ and $12.7 \mathrm{~mm}$ to $23.1 \mathrm{~mm}$ respectively. The higher worth was found for tested Gram-negative microbes when contrasted with tested Gram positive microscopic organisms. According to above conversation it is clear that the most elevated hindrance zone detailed for Escherchia coli which are $22.6 \mathrm{~mm}, 23.1 \mathrm{~mm}$ and $23.3 \mathrm{~mm}$ for leaves, combination (leaves + Berries) and berries individually. Just as the most minimal restraint zone represented Staphylococcus aureus which are $11.8 \mathrm{~mm}, 12.6 \mathrm{~mm}$ and $12.7 \mathrm{~mm}$ for leaves, berries and blend. The normal inhibitory zones of leaves, berries and blend are $17.5 \mathrm{~mm}, 18.2 \mathrm{~mm}$ and $18.56 \mathrm{~mm}$ respectively against tried five types of microbes. The three pieces of Juniperus excelsa have somewhat distinction against the microorganisms, particularly bacteria Based overall, the leaves have the least $(17.5 \mathrm{~mm})$ inhibitory substance against microorganisms, however the berries have the most noteworthy $(18.56 \mathrm{~mm})$.

The plant parts roots and shoots of E. intermedia Schrenk \& Meyer were used in this study and the four bacterial strains comprising of E. coli, P. fluorescens, S. aureus and B. subtilis were used for the estimation of antibacterial activity. Additionally, three fungal strains such as A. flavus, $D$. turcicia and $F$. veriticilliodes were designated for antifungal potential. The antimicrobial activity of $E$. intermedia Schrenk and Meyer against selected bacterial and fungal strains was analyzed by the presence and diameter $(\mathrm{mm})$ of inhibition zones, as noted by [25].

The shoot and root extract substances of Ephedra intermedia were tried against four bacterial strains (Staphylococcus aureus,
Bacillus subtilis, Pseudomonas fluorescens and Escherchia coli). The underlying foundations of $E$. intermedia have the most elevated inhibitory zone for S. aureus and the most minimal for B. subtilis which are 22 and 15 separately. Just as, the shoots have the most minimal inhibitory zone for $B$. subtilis (11) and the most noteworthy for $S$. aureus (19). The normal of roots substance have the higher antibacterial movement when contrasted with shoots which are $18.25 \mathrm{~mm}$ and $15 \mathrm{~mm}$. The roots and shoots of $E$. intermedia have the greatest antimicrobial (Antibacterial) movement against the $S$. aureus of microorganisms. Notwithstanding, the roots and shoots of E. intermedia have recorded the base action according to tried to B. subtilis. The normal of roots and shoots substance against the tried microscopic organisms: Staphylococcus aureus has the most noteworthy hindrance zone however the Bacillus subtilis has the least one when contrasted with different types of microorganisms.

\section{Conclusion}

The aforementioned research reviewed that the selected plants (Juniperus excelsa and Ephedra intermadai) have highly impacts against bacterial strains. Consequently, the outcomes display the chance of utilizing these concentrates for the illness of destructive diseases. The research further presumes that the berries, leaves and their mixture of Juniperus excelsa is better dynamic for microbial exercises. As well as, Ephedra intermadia has also a high effect against bacterial strains. Thus, it is very well may be reasoned that the two plants have restorative properties against wide scope of bacterial and contagious strains and can be utilized as better substitute to costly medications accessible in market.

\section{Authors' contributions}

Conceived and designed the experiments: SU Rehman, Performed the experiments: MU Rehman, Analyzed the data: MU Rehman \& M Idrees, Contributed reagents/ materials/ analysis tools: SK Leghari, KU Rehman, AKK Achakzai, B Zareen, BS Zaman \& A 
Malik, Wrote the paper: MU Rehman \& SU Rehman.

\section{References}

1. Farnsworth NR \& Soejarto DD (1991). Global importance of medicinal plants. In: Akerele, O, Heywood V, Synge $\mathrm{H}$ (Eds.). The Conservation of Medicinal Plants. Cambridge University Press, Cambridge. pp. 25-52.

2. Bhalodia NR \& Shukla VJ (2011). Antibacterial and antifungal activities from leaf extracts of Cassia fistula 1: An ethnomedicinal plant. $J$ of Adv Pharma Technol \& Res 2: 104-109.

3. Pushpa H \& Purushothama KB (2010). Antimicrobial activity of Lyophyllum decastes an edible wild mushroom. World J of Agric Sci 6(5): 506-509

4. Kumar AO, Mutyala NL \& Raja Rao KG (2010). Antibacterial Evaluation of Snake Weed (Euphorbia Hirta L.). Inter J of Pharm Tech Res 2: 1383-1385.

5. Suneetha G \& Ravi V (2013). Antimicrobial Activity of Andrographis paniculata Flower $\quad$ Extracts. Inter J of Res and Rev in Pharma and Appl Sci 2: 604-610.

6. Deepak S, Pawar A \& Shinde P (2014). Study of antioxidant and antimicrobial activities of Andrographis paniculate. Asian J of Plant Sci and Res 4: 31-41.

7. Rahman SA, Abd-Ellatif SA, Deraz SF \& Khalil AA (2011). Antibacterial activity of some wild medicinal plants collected from western Mediterranean coast, Egypt: Natural alternatives for infectious disease treatment. Afr J of Biotechnol 10: 1073310743.

8. Martins AP, Salgueiro L, Goncalves MJ, Proencacunha V, Vila R, Canigueral S, Mazzoni V (2001). Essential oil composition and antimicrobial activity of three Zingiberaceae from S. Tomeeprincipe. J of Planta Medica 67: 580- 584.

9. Shahraki J, Sardarshahaki A \& Hubshmi SES (2018). Economic impact assessment of water resources management scenarios in Pishin catchment. J of Agric Econ Res 10(4):

\section{Pe59-Pe84.}

10. Ikram M, Jan G, Khan SD, Jan FG, Ullah A, Shaheen S, Ijaz F, Rehman S, Bahadar S, Ziaulhaq, Ali A \& Iqbal Z (2015). Antimicrobial Activity and Phytochemical Screening of Artemisia annua L. and Millotus philippensis (Lam.) Mull. Arg. Leaves. AmericanEurasian J Agric \& Environ. Sci 15(12): 2437-2441.

11. Bibii T, Ahmad A, Baloch AI, Muhammad S \& Manzoor R (2017). Ethnomedicinal uses of plants for child birth and postpartum recovery in district Pishin, Northern Baluchistan, and Pakistan, Inter J Biol Pharma and All Sci 6: 1730-1760.

12. Demisse H \& Wgebrial S (2018). Phytochemical Screening and In-Vitro Acaricidal Activity of Three Herbal Ext racts against Cattle Tick Boophilus Decoloratus. IJP 5.

13. Mohamed M, Deabes, Abdou K, Allayeh, Seif MM, Abdel-Hamied M, Rasmey \& Naguib KM (2020). Antiviral, Antifungal, and Antibacterial Potential Activities of Ephedra Sinica in Vitro. Jordan Journal of Biological Sciences Volume 13, Number 3, September 2020.

14. Nabi S, Ahmed N, Khan MJ, Bazai Z, Yasinzai M \& Al-Kahraman YMSA (2012). In vitro Antileishmanial, Antitumor Activities and Phytochemical Studies of Methanolic Extract and its Fractions of Juniperus Excelsa Berrie. World Appl Sci J 19(10): 1495-1500, 2012.

15. Javid T, Adnan M, Tariq A, Akhtar B, Ullah R \& Abd El Salam NM (2015). Antimicrobial activity of three medicinal plants (Artemisia indica, Medicago falcate and Tecoma stans). Afri J of Trad, Compl and Alter Med 12(3).

16. Lupoae M, Coprean D, Dinică R, Lupoae P, Gurau G \& Bahrim G (2013). Antimicrobial Activity of Extracts of Wild Garlic (Allium ursinum) from Romanian Spontaneous Flora. 14(4): 221 $-227$.

17. Selvamohan T, Valli TM \& Sujitha $S$ 
(2010). Antimicrobial activity and phytochemical studies on some Indian medicinal plants against selected human pathogens. Der Pharma Chemica 2(5): $38-45$.

18. Zaidi MA \& Crow SA (2012). Cytotxicity of Four Medicinal Plants of Pakistan. Pak J Bot 44(SI): 395-397.

19. Doughari JH (2006). Antimicrobial Activity of Tamarindus indica L. Trop $J$ of Pharma Res 5: 597-603.

20. Chaman S, Sharma G, Shalini \& Reshi AK (2013). Study of Antimicrobial properties of Catharanthus roses by Agar Well Diffusion method. Inter Res J of Pharma and Appl Sci 5: 65-68.

21. Weli AM, Al-Hinai SRK, Hossain MM \& Al-Sabahi JN (2014). Composition of essential oil of Omani Juniperus excelsa fruit and antimicrobial activity against food borne pathogenic bacteria. $J$ of Taibah Uni for Sci 8(3): 225-230.
22. Unlu M, Varder-Unlu G, Vural N, Donmez E \& Cakmak O (2008). Composition and antimicrobial activity of Juniperus excelsa essential oil. Chem Nat Compd 44: 129-131.

23. Cos P, Vlietinck AJ, Berghe DV \& Maes L (2006). Anti-infective potential of natural products: how to develop a stronger in vitro 'proof-of-concept'. $J$ Ethnopharmacol 106(3): 290-302.

24. Khoury M, El-Beyrouthy M, Ouaini N, Iriti M, Eparvier V \& Stien D (2014). Chemical Composition and Antimicrobial Activity of the Essential Oil of Juniperus excelsa M.Bieb. Growing Wild in Lebanon. Chem Biodivers 11(5): 825-830.

25. Bangulzai MS, Leghari SK, Ali,I Asrar M, Ismail T \& Mushtaq A (2017). Antimicrobial analysis of root and shoot extracts of Ephedra intermedia Schrenk \& Meyer. Inter J of Biosci 11(3): 86-94. 